\title{
THE ABSOLUTE ANONYMITY OF A STATE WITNESS
}

\author{
BC Naudé \\ Bluris LLB LLD \\ Professor of Law \\ University of South Africa (UNISA)
}

\section{SUMMARY}

An important facet of the principle of open justice is the right of the accused to challenge the evidence given against him or her. When a witness testifies anonymously, the potential exists for an improper infringement of this right. Although the right to challenge evidence is not absolute, it is not easy to identify the circumstances that would provide justification for an infringement of this essential right. While the interests of justice is a determining factor, it is necessary for legislation to be put into place to set out specific circumstances to guide the courts whether or when to allow anonymous testimony. In addition, provision should be made for the appointment of an independent investigator to assist the court to investigate the credibility of the witness. Further, if witness anonymity orders are limited to serious cases and only allowed in exceptional circumstances, there is no reason why anonymous testimony should not be allowed.

\section{INTRODUCTION}

That criminal proceedings must take place in an open court and in the presence of the accused has long been a fundamental principle of our common law ${ }^{1}$ and is codified in section 152 of the Criminal Procedure Act 51 of 1977 which states that "except where otherwise expressly provided by this Act or any other law, criminal proceedings in any court shall take place in open court, and may take place on any day". The Constitution ${ }^{2}$ further

1 In S v Leepile (1) 19862 SA 333 (W) 339B-C, the court quotes Lord Shaw in Scott $v$ Scott [1913] AC 417 and Lord Diplock in Harman v Home Office [1983] AC 280 who had, in turn, quoted Bentham as saying that: "Publicity is the very soul of justice. It is the keenest spur to exertion, and the surest of all guards against improbity. It keeps the Judge himself, while trying, under trial." See also the remarks made by Kriegler $\mathrm{J}$ in $S$ v Mamabolo 20011 SACR 686 (CC) par 18-19 and par 29-31; par 23-55 of the majority judgment in South African Broadcasting Corporation Ltd v National Director of Public Prosecutions 20071 SACR 408 (CC); and the remarks made by Yacoob J in Shinga $v$ The State; O'Connel $v$ The State 20072 SACR 28 (CC) par 25. In this last-mentioned case, Yacoob J remarks (par 26): "Seeing justice done in court enhances public confidence in the criminal-justice process and assists victims, the accused and the broader community to accept the legitimacy of that process. Open courtrooms foster judicial excellence, thus rendering courts accountable and legitimate. Where criminal appeals are to be dealt with behind closed doors, faith in the criminal-justice system may be lost. No democratic society can risk losing faith. It is for this reason that the principle of open justice is an important principle in a democracy." For a recent English decision that restates this principle, see $R v$ Davis [2008] UKHL 36 par 5.

2 Act 108 of 1996. 
recognizes this principle in section $35(3)$ (c) by stating that every accused person has the right to a fair trial, which includes the right "to a public trial before an ordinary court". ${ }^{3}$ In addition, it can also be argued that the public have a legitimate interest in all criminal trials and are entitled to be kept informed in this regard. ${ }^{4}$

The principle of open justice therefore contains two facets:

- Firstly, openness is seen as an important component of a fair trial.

- Secondly, openness includes the element of publicity and the right of members of society to be kept informed of the conduct of criminal trials, and the administration of justice therefore benefits from the publicity given to court proceedings.

Section 153 of the Criminal Procedure Act 51 of 1977 provides for exceptions ${ }^{5}$ to the open justice principle in criminal proceedings and inter alia states that if it appears to the court that there is a likelihood that harm might result to any witness if he or she testifies at such proceedings, the court may direct that such a person shall testify behind closed doors and that no person shall be present when such evidence is given unless his or her presence is necessary in connection with such proceedings or is authorized by the court. ${ }^{6}$ The court may further order that the identity of such witness shall not be revealed or that it shall not be revealed for a period specified by the court. ${ }^{7}$ Subject to these provisions, a court may further order that a witness, if the witness or the accused consents thereto, may give evidence by means of closed circuit television or similar electronic media. ${ }^{8}$ In order to ensure a fair and just trial, a court may make the giving of such evidence subject to such conditions as it may deem necessary, but the prosecutor and the accused have the right, by means of that procedure, to question a witness and to observe his or her reaction. ${ }^{9}$

3 Other constitutional provisions that are relevant here are $s 1(d)$, which entrenches accountability, responsiveness and openness in democratic governance as founding values, and s 34, which entrenches a fundamental right of access to the courts - see generally Young $v$ Minister of Safety and Security 20052 SACR 437 (SE) par 13 et seq and the cases referred to by Plasket $\mathrm{J}$.

4 In S v Geiges 20072 SACR 507 (T) par 52, Labuschagne J states: "In my view, the public have a legitimate interest in all criminal trials and are entitled to be kept informed in that regard. I am inclined to agree with the State's submission that $s$ 16(1)(a) and (b) of the Constitution recognize and protect a broader element of the principle of open justice which focuses, not on the accused's right to a fair trial, but on the public's right to be informed of the conduct of all criminal proceedings and the importance for the administration of justice that they be so informed."

5 See, generally, $S$ v Baleka (2) 19864 SA 200 (T) 201G. Such a discretion existed in the common law as well - see generally S v Manqina 19942 SACR 692 (C) $701 \mathrm{~b}$ et seq. Also see s 16 of the Supreme Court Act 59 of 1959 that provides: "Save as is otherwise provided for in any law, all proceedings in any court of a division shall, except in so far as any such court may in special cases otherwise direct, be carried on in open court."

6 S 153(2)(a) of the Criminal Procedure Act 51 of 1977

7 S 153(2)(b) of the Criminal Procedure Act 51 of 1977. Also see s 154 of the Criminal Procedure Act that permits a court to prohibit the publication of certain information relating to criminal proceedings.

8 S 158(2) of the Criminal Procedure Act 51 of 1977.

9 See s 158(4) of the Criminal Procedure Act 51 of 1977. 
It is understandable that the identity of a witness should, in appropriate circumstances, be withheld from the public, but it is questionable whether the mentioned provisions allow for the non-disclosure of the identity of state witnesses to the accused and his or her representatives or even to the court itself, since such an outcome would not only be against general common law principles, but would also infringe the right of the accused to a fair trial. ${ }^{10}$ This issue has arisen in only a limited number of cases, with some cases recognizing that if it is necessary in the interests of justice that the identity of a state witness should be withheld from the accused and his or her representative, the court is entitled and empowered by section 153(2) of the Criminal Procedure Act 51 of 1977 to grant an order to that effect. ${ }^{11}$ Such an order will, however, only be granted in exceptional cases and could be reversed in order to ensure that the accused has a fair trial, even after an initial ruling to the contrary. It is submitted that there is good reason to support this approach: not only is it in line with thinking in other common law jurisdictions, ${ }^{12}$ but useful and necessary to combat serious organized and gang-related crime. It also takes away the need to make complex decisions when the police or journalists ${ }^{13}$ cannot reveal the sources of their information and it could also lessen the need for having witness protection programmes that often cause the significant limitation of certain rights. ${ }^{14}$

\section{GENERAL APPROACH TO SECTION 153(2) OF THE CRIMINAL PROCEDURE ACT}

Before a court can make an order in terms of section 153(2) of the Criminal Procedure Act 51 of 1977, it must first be established "that there is a likelihood that harm might result to any person". ${ }^{15}$ This phrase has been

10 Non-disclosure would, for example, be achieved by allowing witnesses to withhold their names and addresses and to give evidence from behind screens and by means of voicedistorting technology.

11 See $S$ v Pastoors 19864 SA 222 (W); and S v Ntoae 20001 SACR 17 (W). See, however, $S \vee$ Leepile (5) 19864 SA 187 (W); S v Niesewand (1) 19733 SA 581 (RA); S v Manqina supra; and $S$ v Nzama 19971 SACR 542 (D).

12 Except that other established common law jurisdictions allow anonymity orders, a recent study by the Law Society of England and Wales showed that only six member states throughout the European Convention now have provisions against anonymity, and two of those are in the process of repealing them - see Ede and Ford Study of the Law of Evidence in Criminal Proceedings Throughout the EU (2004) 13.

13 See, eg, the facts in the recent decision by the Canadian Supreme Court in $R v$ National Post [2010] SCC 16.

14 Comparet-Cassani "Balancing the Anonymity of Threatened Witnesses versus a Defendant's Right of Confrontation: The Waiver Doctrine after Alvarado" 200239 San Diego L Rev 11651237 points out that placement in such programmes: "[R]esults in the loss of those constitutional rights granted to all citizens, such as freedom of association, ... which includes the creation and sustenance of a family, marriage, educating and raising children, and cohabitation with one's relatives; ... the right to life and liberty; ... the right to freedom of personal choice in the matters of family life; ... the right to freely travel; the right to establish one's home and move about at will; ... the right to contract and engage in any of the common occupations of life; and the right to enjoy those privileges long recognized at common law as essential to the orderly pursuit of happiness by free men."

15 See $S v$ Leepile (1) supra $335 \mathrm{H}-J$. The harm may take on any form and the nature thereof is a consideration when exercising the discretion conferred by this section. For an example of 
interpreted to mean that the likelihood of harm must be a reasonable possibility and not a far-fetched one, although this does not mean that a probability must exist that harm will result. ${ }^{16}$ Much will depend on the circumstances of a particular case and a court is allowed to venture beyond the factual evidence placed before it as direct proof of the likelihood of harm resulting. ${ }^{17}$ A court can, for example, draw upon its own judicial experience in similar cases, and consider the nature of the relevant crime, and take into account the atmosphere of the specific case. ${ }^{18}$

Once the jurisdictional facts have been established, ${ }^{19}$ the court must exercise its discretion, but it is not compelled to make an order. This discretion involves a careful weighing up of the factors that favour an open trial against those factors that favour protecting a witness from harm. ${ }^{20}$ Due regard should therefore be given to the possible rights of witnesses, especially when they are crucial witnesses in serious criminal cases. ${ }^{21}$ It can be argued that state bodies are under a positive obligation to take preventative operational measures to protect an individual whose life is at risk, because they are going to testify about the criminal acts of another individual. ${ }^{22}$

a case where an application in terms of $s$ 153(2) was initially granted, but later set aside, see $S v$ Yengeni 19902 SACR 248 (C).

16 See S v Madlavu 19784 SA 218 (E) 222G; S v Leepile (1) supra 341A-D; and S v Baleka (2) supra 202B.

17 See S v Madlavu supra 222H-223A; S v Leepile (1) supra 341B-D; and S v Sekete 19801 SA $171(\mathrm{~N}) 172 \mathrm{~F}$.

18 In S v Mothopeng 19784 SA 874 (T) $876 \mathrm{H}$ the court remarks: "It must appear to me that there is a likelihood of harm to the witnesses or to other persons. This must in the ultimate result depend on a number of factors, none of which can be determined with computer-like accuracy. The charge-sheet, the allegations therein, the judicial experience of the Judge, the atmosphere of the case, the type of case, past examples, the type of witness concerned and so forth, all these must be taken into account."

19 In other words there must be a causal connection between the act of testifying and the harm to the witness. Cf the decision by the European Court of Human Rights in Visser $v$ The Netherlands App. No. 26668/95, 14 February 2002, where the court found that the domestic court had improperly issued an anonymity order on the ground that the applicant's coaccused had a history of violence; there was no evidence that the individual in question intended to harm the applicant.

20 See $S v$ Leepile (1) supra 340A-B; and S v Ntoae supra 22d. In S v Leepile (1) supra 340E$\mathrm{F}$ Ackermann $\mathrm{J}$ points out that a witness must testify free from the fear of reprisals in order to ensure that his or her testimony is not distorted by such fear. Another important point is the reality that witnesses do their civic duty by testifying in court. Ackermann $\mathrm{J}$ notes $(340 \mathrm{I})$ : "After all, the primary object of the subsection is not to protect witnesses, but to ensure that justice is done."

21 See Comparet-Cassani 200239 San Diego L Rev 1233 for a discussion in the American context and J Doak Victims' Rights, Human Rights and Criminal Justice: Reconceiving the Role of Third Parties (2008) Chapter 2 for a discussion in the European context. See also $R$ $v$ Mayers [2009] $1 \mathrm{Cr}$ App R 30 par 6, where the court inter alia notes that a judge's role in considering an anonymity order involves a 'delicate balance' between the accused's fair trial rights under article 6 of the European Convention on Human Rights and those of witnesses under articles 2 (life), 3 (physical integrity) and 8 (private life) and also the decision by the European Court of Human Rights in Doorson v The Netherlands (1996) 22 EHRR 330. See further Gillespie and Bettison "Preventing Secondary Victimisation Through Anonymity" 200770 MLR 114.

22 Cf Osman v United Kingdom [1999] EHRLR 228 (in relation to article 2); and $A v$ United Kingdom (1999) 27 EHRR 611 (in relation to article 3). Also see Van Colle $v$ Chief Constable of Hertfordshire; Smith $v$ Chief Constable of Sussex [2009] 1 AC 225. Similar 
If witnesses are allowed to be intimidated, both integrity of the criminal justice system and the faith in the government's ability to protect the public will be jeopardized. Citizens must further be encouraged to report their knowledge of criminal activity, since citizen co-operation is critical to law enforcement.

In considering an anonymity order, the court is confronted with a conflict of interests and must protect those interests which, on the facts of the particular case, weigh in favour of the proper administration of justice. ${ }^{23}$ Any order should therefore not go further than is required by the demands of the case, and must ensure that the proceedings are fair to all the parties concerned.

\section{SECTION 153(2) AND THE ANONYMOUS WITNESS}

It is an illusion to think that an ordinary in camera hearing would hide the identity of a witness from those seeking retribution against him or her. The court may order that the witness be excused from disclosing his or her real name to the court or that the witness is allowed to adopt any pseudonym for the purpose of the trial. The court may further order that no person is allowed to reveal the identity of the witness and that his or her evidence only be published to the extent that it does not tend to disclose the witness's identity or to the extent that it may not or could not be used to establish the witness's identity. The accused will, however, know the witness's identity

sentiments have been expressed in the South African context - see Carmichele $v$ Minister of Safety and Security 20014 SA 938 (CC), where the Constitutional Court inter alia referred with approval (par 44-45) to Osman $v$ United Kingdom supra.

23 Cf $S$ v Pastoors supra 225J-226B. See also $S$ v Du Toit 20051 SACR 47 (T), where an application in terms of $S$ 153(2)(b) was denied. Chadbourn Wigmore on Evidence Revision Vol 6 (1976) par 1834, (referred to by Friedman JP in $S$ v Manqina supra 700d), points out that the reason for the requirement of publicity is twofold: First, publicity is seen as a security for trustworthiness and completeness of testimony and secondly, publicity is seen to have other advantages in view. As far as the first reason is concerned, its operation in improving the quality of testimony is twofold: "Subjectively, it produces in the witness's" mind a disinclination to falsify; first by stimulating the instinctive responsibility to public opinion, symbolized in the audience, and ready to scorn a demonstrated liar; and next, by including the fear of exposure of subsequent falsities through disclosure by informed persons who may chance to be present or to hear of the testimony from others present. Objectively, it secures the presence of those who by possibility may be able to furnish testimony in chief or to contradict falsifiers and yet may not have been known beforehand to the parties to possess any information. Wigmore further points out the other advantages that are of three distinct sorts: "(a) Subjectively a wholesome effect is produced, analogous to that secured for witnesses upon all the officers of the court, in particular upon Judge, jury and counsel. In acting under the public gaze they are more strongly moved to a strict conscientiousness in the performance of duty. In all experience secret tribunals have exhibited abuses which have been wanting in courts whose procedure was public. (b) Persons not called as parties to the suits before the court may nevertheless be affected or think themselves likely to be affected by pending litigation. They should have the opportunity of learning whether they are thus affected and of protecting themselves accordingly. They have 'a right to be present for the purpose of hearing what is going on'. (c) The educative effect of public attendance is a material advantage, not only is respect for the law increased and intelligent acquaintance acquired with the methods of government, but a strong confidence in judicial remedies is secured which would be inspired by a system of secrecy." 
and the facts he or she deposes to and will surely give such details to any visitors he or she may receive. It could also be necessary for the counsel for the accused to disclose such particulars when consulting their own defence witnesses. Clearly there is a need for absolute anonymity of state witnesses in certain cases. Although it should be possible to apply section 153(2) of the Criminal Procedure Act 51 of 1977 to a situation where an application is made for the non-disclosure of the identity of state witnesses to the accused and his or her representatives or even to the court itself, it is necessary to consider the dangers of anonymous testimony in order to place a proper limitation on the right of the accused's right to challenge evidence. ${ }^{24}$

\section{THE PITFALLS OF ANONYMOUS TESTIMONY}

There are some obvious problems caused by allowing a witness to testify anonymously. ${ }^{25}$ Firstly, no investigation can be undertaken into the witness's background to establish whether he or she has a general reputation for untruthfulness, whether he or she has made previous inconsistent statements or to consider other matters which might be relevant to credibility. Anonymous testimony would also make it difficult to determine whether a witness has ulterior motives or was perhaps involved in the crime and wants to shift blame. ${ }^{26}$ Because the court is unable to observe the demeanour of the witness as he or she testifies, it would impact on the court's ability to assess the credibility of the witness. ${ }^{27}$ In addition,

24 S 35(3)(i) of the Constitution 108 of 1996 states: "Every accused person has the right to a fair trial, which includes the right - (i) to adduce and challenge evidence; ..."

25 See generally the remarks made by Ackermann $\mathrm{J}$ in $S$ v Leepile (5) supra 189E-190E.

26 See $S \vee$ Nzama supra. In this case counsel for the state applied for an order that a state witness be permitted to testify in such disguise as would preclude the accused, the court or anyone else from being aware of what he looked like and of his identity. The court held that it is a fundamental principle of our criminal procedure that an accused person is entitled to a fair trial in open court save in exceptional circumstances. An accused could not have a fair trial unless he or she is able properly to exercise the right to cross-examine witnesses called by the state and to lead evidence in his or her own defence. The court noted that it was incomprehensible that an accused could properly exercise those rights in relation to a witness whose face was completely unrecognisable to him and whose name was also withheld from him. The court notes $(543 \mathrm{e}-\mathrm{i})$ : "One does not need to tax one's imagination to see where a principle which authorised this would lead an accused person. For example, the witness may be a person who in fact has a grudge against the accused and seeks falsely to give evidence against him. How is the accused to be able to cross-examine this witness, or to give his legal representative instructions to cross-examine this witness, on any effective basis if he does not know who the person is and therefore that this very person is in fact one who holds a grudge against him? ... I may add that it is also quite obscure to me how this court is to be expected to be able to judge the credibility of a witness if the court cannot see his features and cannot inform itself by observation of how he reacts to questions which may be put to him."

27 About how demeanour can possibly affect credibility - see Schwikkard and Van der Merwe Principles of Evidence 3ed (2009) 534-537. It would, however, be wrong to assume that those who are lying display behavioural sign of lying, or that those who are telling the truth won't show signs of lying - see generally Vrij Detecting Lies and Deceit: The Psychology of Lying and Implications for Professional Practice (2000); and Stone "Instant Lie Detection? Demeanour and Credibility in Criminal Trials" 1991 Crim LR 821. 
anonymous testimony could possibly increase a witness's temptation to falsify or exaggerate.

Secondly, it would be difficult to establish whether the witness was or was not present at the places on the occasions mentioned by him or her. ${ }^{29}$ Therefore, it could be difficult to obtain complete information about the witness's location and ability to observe, and testify about, the crime.

If a witness is allowed to testify anonymously, it can also be asked how much information can be obtained from a witness regarding such matters as birth, training, marital status, family, residence and general biographical detail before there is risk of infringing the court's order. ${ }^{30}$

The main difficulty caused by the above-mentioned problems is that it would be difficult to justify absolute anonymity when the witness is a crucial witness in the case and his or her credibility is clearly relevant. Effective cross-examination would simply not be possible in such a case. ${ }^{31}$ In Alvarado $v$ Superior Court, ${ }^{32}$ for example, a prisoner was murdered in jail and there were other remaining prisoners who were crucial witnesses for the prosecution. Owing to their prior criminal histories, the credibility of these witnesses was necessarily an important issue in the case. It is not only the prior criminal history, especially with regards to crimes showing moral turpitude that affects credibility, but also a witness's motivation to testify.

28 Comparet-Cassani 200239 San Diego L Rev 1183 points out: "The physical presence of the accused is meant to contribute to the reliability of the evidence by bolstering the likelihood that witnesses will tell the truth. Facing a defendant while testifying under oath impresses upon witnesses the seriousness of the matter and subjects witnesses to the penalty of perjury if they lie." Some psychologists have, however, demonstrated this assumption to be false - see Spencer and Flin The Evidence of Children (1993).

29 For an interesting discussion on how cultural factors can affect witness testimony, see Pozen "Justice Obscured: The Non-disclosure of Witnesses' Identities in ICTR Trials" 2005200638 NYUJ Int'IL\&Pol 281308 . With reference to the Rwandan context, she points out inter alia that the accused's right to cross-examine prosecution witnesses is particularly important because of viewpoint inconsistencies in Rwandan oral culture. Rwandans tend to relay information as if they were an eyewitness to an event even when information is learned second- or third-hand. This tendency to narrate in the first person brings into relief the importance of cross-examination to correctly identify the relationship of a witness to an event.

30 The court in $S \vee v$ Leepile (5) supra190D also points out: "If counsel by chance should become aware of the witness's true identity and this leads to the discovery of valuable information regarding the witness's credibility, may this information not be used in crossexamination if it involves disclosure or verification of the witness's true identity?"

31 Compare the position in the USA where in Smith $v$ Illinois 390 US 129 (1968) the court noted (131) that: "[W]hen the credibility of a witness is in issue, the very starting point ... must necessarily be to ask the witness who he is and where he lives. The witness's name and address open countless avenues of in-court examinations and out-of-court investigations. To forbid this most rudimentary inquiry at the threshold is to effectively emasculate the right of cross-examination itself." The right of an accused under the Sixth Amendment "to be confronted with the witnesses against him" has recently been interpreted in an absolute sense by the majority of the US Supreme Court in Crawford $v$ Washington 124 S.Ct. 1354 (2004); and in Melendez-Diaz v Massachusets 129 S.Ct. 2527 (2009). See, however, Allen "The Working and Rationale of the Hearsay Rule and the Implications of Modern Psychological Knowledge" 1991 CLP 217, pointing out that although crossexamination is useful for exposing ambiguity and inconsistency in witness's accounts, it is a poor mechanism in terms of exposing outright lying.

32 See the decision by the California Supreme Court in Alvarado v Superior Court 5 P.3d 203 (Cal 2000). 
Such a witness may, for example, testify in return for special treatment from the authorities, such as leniency in a pending criminal case or they could have previously received a benefit for testifying.

Allowing a witness to testify anonymously when such a witness is the "sole or decisive evidence" against the accused is also a controversial issue. ${ }^{33}$ In $R v$ Davis $^{34}$ the House of Lords decided that there was no fair trial on the evidence of an anonymous witness who provided the sole or decisive evidence against the accused. ${ }^{35}$ The decision by the House of Lords in $R v$ Davis was, however, undone by emergency legislation ${ }^{36}$ and final legislation in this regard is currently contained in Chapter 2 of the Coroners of Justice Act of $2009 .{ }^{37}$ In $R v$ Horncastle ${ }^{38}$ the UK Supreme Court also decided that there is no requirement in English law that a conviction cannot be based on the sole or decisive evidence of an absent witness and that the same holds true for an anonymous witness. ${ }^{39}$ On its own, the "sole or decisive evidencetest" cannot be supported. If evidence is reliable, the fact that such evidence is the sole or decisive evidence against the accused should not matter. In the end, it is up to the court to decide whether the accused's guilt has been

33 This principle originated in the European Court of Human Rights. In Doorson $v$ The Netherlands supra the court found justification for admitting the statements of an absent witness and for the anonymity of two witnesses, but noted that: "Finally, it should be recalled that, even when 'counterbalancing' procedures are found to compensate sufficiently the handicaps under which the defence labours, a conviction should not be based either solely or to a decisive extent on anonymous statements." The decision therefore recognizes that even where there was justification for not calling a witness, basing a conviction solely or decisively on the evidence of that witness would be unfair. No explanation was given for the principle underlying this test and in $R v$ Horncastle [2009] UKSC 14 par 86 Lord Phillips points out that: "[T]he Strasbourg Court has not subsequently explained why a conviction based in part on the evidence of a witness who was not called, or who was anonymous, need not offend article 6(1) and (3)(d), while, on the contrary, if the evidence is sole or decisive the article will be violated." Lord Phillips did, however, mention that the justification for the sole or decisive test would appear to be that the risk of an unsafe conviction based solely or decisively on anonymous or hearsay evidence is so great that such a conviction can never be permitted.

34 Supra.

35 The European Court of Human Rights follows the same principle - see Al-Khawaja and Tahery $v$ UK (2009) 49 EHHR 1. (This decision is currently being reviewed by the Grand Chamber of the European Court of Human Rights and a hearing in this regard took place on 19 May 2010. Article 6(3)(d) of the European Convention on Human Rights is relevant in this regard and guarantees an accused a "right to examine or have examined witnesses against him".

36 See the Criminal Evidence (Witness Anonymity) Act of 2008.

37 See generally Swergold "Taking 'Blind Shots at a Hidden Target': Witness Anonymity in the United Kingdom" 200932 BC Int'I\&Comp L Rev 471; Doak and Huxley-Binns "Anonymous witnesses in England and Wales: Charting a course from Strasbourg?" $200973 \mathrm{~J}$ Crim L 508; Bagshaw "Anonymous Evidence: $R$ v Mayers" 200913 E\&P 137; and Ward "The Evidence of Anonymous Witnesses in Criminal Matters: Now and Into the Future" 200921 Denning $L J 67$. For a recent decision dealing with the relevant legislation, see $R v$ Chisholm [2010] EWCA Crim 258.

38 Supra.

39 Other established common law jurisdictions do not recognize a rigid rule excluding hearsay evidence if it is the sole or decisive evidence - see Annexure 1 of $R v$ Horncastle supra for a summary of the position in Canada, Australia and New Zealand. 
proved beyond a reasonable doubt in view of all the circumstances of the specific case. ${ }^{40}$

Allowing the absolute anonymity of a witness would draw many of the same points of criticism that exist against the admissibility of hearsay evidence in terms of section 3(1)(c) of the Law of Evidence Amendment Act 45 of $1988{ }^{41}$ In the context of hearsay evidence our highest courts have, however, indicated that the right to challenge evidence is not an absolute right. ${ }^{42}$ If it is possible to allow hearsay evidence, it should all the more be possible to allow the absolute anonymity of a state witness in appropriate circumstances: in the case of an anonymous witness the witness is in court and can be cross-examined, even though it might not always be possible to explore fully the witness's credibility. ${ }^{43}$ A court will, however, have to guard against a witness not being adequately cross-examined and section 153(2) of the Criminal Procedure Act 51 of 1977 should therefore not be used to prevent the defence from presenting its case properly. ${ }^{44}$ If this is ensured, there is no reason why the identity of the witness cannot in appropriate circumstances be withheld from the accused or the court. As Navsa J points out in $S v$ Ntoae ${ }^{45}$ section 153(2) is intended "to aid the administration of justice by ensuring that members of the public who do their civic duty and come forward to do so can testify without fear of reprisals".

40 See also $R v$ Horncastle supra par 87 et seq for an explanation of the practical difficulties of applying such a test.

41 As far as anonymous testimony is concerned, some commentators are vehemently opposed to any limitation of the right to challenge evidence and cannot envisage anything other than full and proper cross-examination of all state witnesses. Such commentators, however, fail to attack the general admissibility of hearsay evidence that places similar limitations on the right to challenge evidence - see generally Lusty "Anonymous Accusers: An Historical and Comparative Analysis of Secret Witnesses in Criminal Trials" 200224 Sydney L Rev 361.

42 In S v Ndhlovu 20022 SACR 325 (SCA) 340f the Supreme Court of Appeal found that the right to challenge evidence does not necessarily include the right to cross-examine the original declarant. (See from 337a where Cameron JA explains why the "scheme and formulation" of the relevant provisions of Act 45 of 1988 are in line with the Constitution). For a discussion in this regard, see BC Naudé "'Testimonial' Hearsay and the Right to Challenge Evidence" 20063 SACJ 320.

43 Compare the remarks made by the UK Supreme Court in $R v$ Horncastle supra par 31-35. For an insightful discussion of the right to confrontation in Europe and America, see Redmayne LSE Law, Society and Economy Working Papers 10/2010.

44 Many of the same factors that a court considers in exercising a discretion to allow hearsay evidence will also be relevant when exercising a discretion whether to allow anonymous testimony - see generally s 3(1)(c) of the Law of Evidence Amendment Act 45 of 1988.

45 Supra 29e. Navsa J further notes: "It appears to me that if a court is of the view that withholding the witness's identity from the accused and counsel is necessary in the interests of justice it is entitled and empowered to do so. Conceivably in a particular case disclosure of a witness's identity to the accused may heighten the witness's fears, and discourage his/her testimony. Such disclosure may conceivably in a particular case ultimately lead to the harm feared by the witness concerned. To hold in such circumstances that disclosure should be made to the accused would render the protection afforded by s 153(2) of the Act illusory. It appears to me that withholding the name of a witness from the court could very rarely if ever be justified ... The court should give due recognition to the accused's right to a fair and public trial ... Every case has to be judged on its own circumstances and facts." 


\section{$5 \quad$ MAIN CIRCUMSTANCES JUSTIFYING ANONYMOUS TESTIMONY}

The right to challenge evidence would not be improperly limited if the court is in possession of facts that would enable a proper appraisal of the credibility of a witness. If "a reasonably complete picture of the witness's veracity, bias and motivation" is therefore established, it is possible to put a reasonable limitation on the right of the accused to challenge the evidence given by an anonymous witness. ${ }^{46}$ The best way to achieve this would be to appoint an independent third attorney and/or investigator who would be provided with the identity of the witness. ${ }^{47}$ The witness's background would then be investigated and the findings reported to the court, but without mentioning the witness's name. ${ }^{48} \mathrm{~A}$ comparable procedure exists in New Zealand, where a judge may appoint independent counsel to assist for the purposes of considering an application for a witness anonymity order in a High Court trial. ${ }^{49}$ Such independent counsel may, inter alia, inquire into matters such as the witness's previous convictions, the witness's relationship with the accused or any associates of the accused..$^{50}$ The party who applies for the witness anonymity order must also make available to the independent counsel all information relating to the proceedings that is in the party's possession. ${ }^{51}$

It would also be proper to limit an accused's right to challenge evidence where it is apparent that the accused is responsible for a witness being unwilling to testify. ${ }^{52}$ Imwinkelreid and Friedman ${ }^{53}$ point out that the accused, by engaging in misconduct or threatening a witness, forfeits his or her normal rights to confrontation. This argument underlies US Federal Rule of Evidence 804(b)(6), which authorizes the admission of "[a] hearsay statement offered against a party that has engaged or acquiesced in wrongdoing that was intended to, and did, procure the unavailability of the declarant as a witness". This is also known as the "principle of forfeiture by misconduct" or the "doctrine of waiver by misconduct" ${ }^{54}$ In US v Dhinsa ${ }^{55}$ the court notes:

46 See US v McLaughlin 957 F.2d 12 (1st Cir. 1992) 17.

47 Alternatively the state must investigate the credibility of any anonymous witness and must also disclose anything capable of challenging it.

48 Cf Comparet-Cassani 200239 San Diego L Rev 1232.

49 See s 115 of the New Zealand Evidence Act of 2006. See also ss 108-109 (specifically dealing with evidence given by undercover police officers and the withholding of their true identities).

50 See s 115(1)(a) of the New Zealand Evidence Act of 2006.

51 See s 115(2). Compare the UK Court of Appeal's decision in $R v$ Mayers supra par 10 where the court points out that before an anonymity order for a civilian witness can be granted, the judge should ensure that a full investigation into the character of the witness occurs, and one which covers his or her credibility and motive for giving evidence, any possible association with the accused (or his or her family) and any possible collusion with other anonymous witnesses, as well as the consequent disclosure of relevant information.

52 See the remarks made by the English Court of Appeal in $R v$ Sellick [2005] EWCA Crim 651 par 52-53 which was referred to with approval in $R v$ Davis supra par 60.

53 Imwinkelreid and Friedman The New Wigmore: A Treatise on Evidence (2009) Chapter 7 1263.

54 See generally Comparet-Cassani 200239 San Diego L Rev 1216 et seq. The author notes (1217): "Succinctly stated, the doctrine provides that if a defendant, through misconduct, 
"Although the right of confrontation is an essential trial right, it may be waived by the defendant's misconduct. Consistent with that principle, this court, as well as a majority of our sister circuits, have ... applied the waiver-by misconduct rule in cases where the defendant has wrongfully procured the witness's silence through threats, actual violence or murder."

This doctrine does not only deal with situations where the accused's direct acts caused the unavailability of a witness, but also instances where a third party has caused such unavailability at the behest of the accused. ${ }^{56}$

\section{RECOMMENDATIONS}

In view of the above, it is recommended that legislation be put into place that contains clear guidelines to assist a court to evaluate any application for anonymous testimony. An anonymity order should only be granted if: ${ }^{57}$

- the safety of the witness or of any other person is likely to be endangered, or there is likely to be serious damage to property, if the witness's identity is revealed and that the witness would hence not testify if the order were not made; ${ }^{58}$ or

- the order is necessary in order to prevent real harm to the public interest ${ }^{59}$ and

- there is no reason to believe that the witness has a motive or tendency to be dishonest, having regard to the witness's previous convictions or the witness's relationship with the accused or any associates of the accused or the circumstances of the case $;{ }^{60}$ or

has prevented a witness from appearing and testifying at his trial, then he has waived his right of confrontation as to that witness and hearsay evidence with respect to that witness's testimony is admissible." This doctrine is firmly rooted in English common law - see Giles $v$ California 128 S.Ct. 2678 (2008) 2683.

55243 F.3d 635 (2d Cir. 2001) 651.

56 See Comparet-Cassani 200239 San Diego L Rev 1221. She points out that, if the waiver by misconduct doctrine were to be used to preclude identifying a witness, it will have to be proved: that the accused, or someone else on his or her behalf, has threatened the life of the witness or a member of the witness's immediate family and has thereby caused the witness's fear; that the accused has the means and capability of carrying out the threat; that the action was taken with the intention of preventing the witness from testifying; and that the witness is in actual fear for his or her life, or for the lives of family members (1224).

57 It is possible to treat anonymity applications on behalf of undercover police officers slightly differently to applications in the case of normal civil witnesses, but a discussion in this regard is beyond the scope of this article - see s 108 of the New Zealand Evidence Act of 2006 for legislative regulation in this regard.

58 Cf s 112(4)(a) of the New Zealand Evidence Act of 2006 and s 88(3)(a) of the Coroners of Justice Act of 2009 (UK). In this regard the court should give consideration to any reasonable fear on the part of the witness that the witness or any other person would suffer death or injury, or that there would be serious damage to property if the witness were to be identified - cf s 88(6) of the Coroners of Justice Act of 2009 (UK).

59 Cf s 88(3)(b) of the Coroners of Justice Act of 2009 (UK).

60 Cf s 112(4)(b)(i) of the New Zealand Evidence Act of 2006 and s 89(2)(e) of the Coroners of Justice Act of 2009 (UK). 
- the witness's credibility can be tested properly without disclosure of the witness's identity; ${ }^{61}$ and

- the making of the order would not deprive the accused of a fair trial. ${ }^{62}$

In considering an application for anonymous testimony, the following specific factors must be taken into account:

- the general right of an accused to know the identity of state witnesses; ${ }^{63}$

- the principle that witness anonymity orders are justified only in exceptional circumstances; ${ }^{64}$

- the seriousness of the offence $;{ }^{65}$

- the extent to which the credibility of the witness concerned would be a relevant factor when the weight of his or her evidence is assessed; ${ }^{66}$

- the importance of the witness's evidence to the case of the party who wishes to call the witness; ${ }^{67}$

- whether it is practical for the witness to be protected by any means other than an anonymity order; ${ }^{68}$

- whether there is any other evidence that corroborates the witness's evidence ${ }^{69}$

- whether evidence given by the witness might be the sole or decisive evidence implicating the defendant; ${ }^{70}$ and

- any other matter that the court considers relevant.

Provision should further be made for independent counsel to assist the court to assess not only the likely truthfulness of any anonymous testimony,

61 Cf s 112(4)(b)(ii) of the New Zealand Evidence Act of 2006 and s 89(2)(d) of the Coroners of Justice Act of 2009 (UK).

62 Cf s 112(4)(c) of the New Zealand Evidence Act of 2006 and s 88(4) of the Coroners of Justice Act of 2009 (UK).

63 Cf s 112(5)(a) of the New Zealand Evidence Act of 2006 and s 89(2)(a) of the Coroners of Justice Act of 2009 (UK).

${ }^{64}$ Cf s 112(5)(b) of the New Zealand Evidence Act of 2006.

65 Cf $s$ 112(5)(c) of the New Zealand Evidence Act of 2006. See also s 110(1), restricting anonymity orders to where a person is "charged with an offence and is proceeded against by indictment", therefore restricting anonymity orders to certain categories of serious cases. The type of proceedings could also be relevant - see generally Haider and Welch "The Protection of Witnesses in Bosnian War Crimes Trials: A Fair Balance Between the Interests of Victims and the Rights of the Accused?" 200820 Denning LJ 55 for a discussion of the considerations that come into play in the case of war crimes trials and the prosecution of extreme violations of human rights.

66 Cf s 89(2)(b) of the Coroners of Justice Act of 2009 (UK). The following remarks made by the UK Court of Appeal Criminal Division in $R v$ Taylor and Crabb (unreported, 22 July 1994) at 17 are apt in this regard: "In this context, it seems to us, that a distinction can properly be drawn, as the learned judge drew it here, between cases where the creditworthiness of the witness is or is likely to be in issue and others where the issue for the jury is the reliability and accuracy of the witness rather than credit."

67 Cf s 112(5)(d) of the New Zealand Evidence Act of 2006.

68 Cf $\mathrm{s} 112(5)(\mathrm{e})$ of the New Zealand Evidence Act of 2006 and s 89(2)(f) of the Coroners of Justice Act of 2009 (UK).

69 Cf s 112(5)(f) of the New Zealand Evidence Act of 2006.

70 Cfs 89(2)(c) of the Coroners of Justice Act of 2009 (UK). 
but also to assist in determining whether an anonymity order should be made in the first place. ${ }^{71}$ Such counsel should be able to access all information that is in the hands of the prosecution. ${ }^{72}$ In addition, it should also be expected from prosecutors who apply for an anonymity order to undertake an active search for material which may undermine witness credibility or the need for an anonymous witness order.

\section{CONCLUSION}

Section 153(2) of the Criminal Procedure Act 51 of 1977 does not provide any specific guidance to a court which has to decide whether a state witness should be allowed to testify anonymously. The only factor to consider is whether there is a likelihood that harm might result to any witness if he or she testifies at criminal proceedings. In this regard, previous decisions seem to have placed the emphasis at the right place, by focusing on the "proper administration of justice" as the determining factor, but perhaps the accused's right to a fair trial has been understated. It is submitted that more should be done in order to ensure a proper limitation of an accused's right to challenge evidence, especially in view of the possible dangers underlying anonymous testimony. Legislation is necessary to set out specific factors that will guide a court in deciding whether to allow anonymous testimony. More importantly, everything should be done to place a court in possession of facts that would enable a proper appraisal of a possible anonymous witness's credibility. In this regard provision should be made for independent investigation into the credibility of an anonymous witness. If anonymous testimony is further confined to serious cases and received only in exceptional circumstances and as a measure of last resort, there is no reason why the absolute anonymity of a state witness cannot be allowed.

Cfs 115(1) of the New Zealand Evidence Act of 2006.

72 Cf s 115(2) of the New Zealand Evidence Act of 2006. See Beresford "The New Zealand Approach to Witness Anonymity and the Right to a Fair Trial" 1998-2000 7 Canterbury L Rev 465 for a discussion of the position in New Zealand before the Evidence Act of 2006 came into force. 